\title{
Foreign Component
}

National Cancer Institute

\section{Source}

National Cancer Institute. Foreign Component. NCI Thesaurus. Code C17957.

An indication that all or part of the research on a grant to a US institution is either

conducted in a foreign country, uses foreign subjects or their tissues or medical data, or involves collaboration with foreign researchers. 